\title{
News, Information and The New International Order
}

\section{Rita Cruise O'Brien}

The worldwide circulation of news has recently become a subject of discussion among developing countries. The Conference of Non-Aligned Countries which took place at Colombo in August, 1976, endorsed a series of proposals for more effective national control over the circulation of news and for the establishment of a news pool within developing regions, based on resolutions prepared by a Conference of Information Ministers and Directors of Press Agencies of the Non-Aligned Countries in Delhi some months earlier.

On the face of it this was a major departure from the post-war ideal of a 'free flow' of information throughout the world, unfettered by national boundaries, and contributing to the enrichment of all people. The 'free flow' notion had been introduced by the United States delegation to UNESCO as early as 1946 . Some commentators in the European press initially viewed it as providing security for the hegemony of US news agencies, but its clear ideological significance became apparent during the Cold War in the 1950s. ${ }^{1}$ For the developing countries the technological and industrial superiority of the rich countries all too easily made this a one-way flow of information from central countries outward.

The circulation of news is complemented by that of television programmes, largely dominated by a small number of firms based on the United States. ${ }^{2}$ These are normally in a position to sell programmes much more cheaply than importing countries can make them locally. The control exercised by the rich countries is also increased because the information and electronic equipment industries are controlled by a few large firms such as Xerox, IBM or ITT.

In coming years the issue of more equitable distribution and control of information will remain on the agendas of policy meetings. But much more research is required to document the elements of control and their effects in the Third World. 3

\section{The Resolutions of the Delhi Conference}

The following excerpts from the resolutions of the Conference of Ministers of Information from Non-Aligned Countries give an idea of the issues involved in the present 'information order' and the proposals for developing country action:

"The Conference noted that:
1. The present global information flows are marked by a serious inadequacy and imbalance. The means of communicating information are concentrated in a few countries. The great majority of countries are reduced to being passive recipients of information which is disseminated from a few centres.

2. This situation perpetuates the colonial era of dependence and domination. It confines judgements and decisions on what should be known, and how it should be made known, into the hands of a few.

3. The dissemination of information rests at present in the hands of a few agencies located in a few developed countries, and the rest of the peoples of the world are forced to see each other, and even themselves, through the medium of these agencies.

4. Just as political and economic dependence are legacies of the era of colonialism, so is the case of dependence in the field of information which in turn retards the achievement of political and economic growth.

5. In a situation where the means of information are dominated and monopolised by a few, freedom of information really comes to mean the freedom of these few to propagate information in the manner of their choosing and the virtual denial to the rest of the right to inform and be informed objectively and accurately.

6. Non-aligned countries have, in particular, been the victims of this phenomenon. Their endeavours, individual or collective, for world peace, justice and for the establishment of an equitable international economic order, have been underplayed or misrepresented by international news media. Their unity has sought to be eroded. Their efforts to safeguard their political and economic independence and stability have been denigrated.

\footnotetext{
1 For an interesting account of the history of this ideological concept, sae H. Schiller, Communication and Cultural Domination, International Arts and Sciences Press, 1976.

$2 \mathrm{~T}$. Varis and $\mathrm{K}$. Nordenstreng, "Television Traffic: A OneWay Street; UNESCO. Reports and Papers on Mass Communications, No. 70, 1974.

3 Recent conferences have called attention to the need for more research in this field. For example, a "Third World Forum Conference in Mexico in May 1976 on the Role of Information in the New International Order. See Development Dialogue, The Dag Hammarskjold Foundation, 1976: 2, which reprints the Conference papers. UNESCO has already which reprints the Conference papsers. UNESCO has already shown an interest by its sponsorship of research on transImpact of Transnational Corporations on Communications, Tamperere Peace Research Reports No. 10, 1975.
} 
7. Non-aligned countries have few means, in the present situation, to know about each other, except through the channel of the existing international news media and news centres, their own news media being mainly underdeveloped or undeveloped for want of required resources. "The Conference reaffirmed the determination of the non-aligned countries not to continue to suffer individually or collectively because of the present inequitable global situation. It was clear that it could be rectified by encouraging constructive and wide-ranging cooperation among themselves for achieving greater collective selfreliance. They expressed commitment to improving of the flow of direct information and fast communication between each other, thereby promoting both greater mutual awareness and understanding of their common political and economic goals and also increasing mutually beneficial cooperation in the social and cultural fields. They stressed that the decolonisation of information is essential for these purposes and that the establishment of a New International Order for Informais as necessary as the New International Economic Order ...."

\section{Western Press Reaction}

The reaction of the Western press to this criticism of the current state of news flows and the creation of a newspool was immediate and hostile. Looking not only at the Delhi resolutions but at a UNESCO meeting on communications planning in Latin America which recommended among other things "the need for state investment in the mass communication sector in accordance with the sector's priorities and responsibilities within overall development planning," many major newspapers and magazines covered the events with a bias reflecting precisely what the Non-Aligned Countries were complaining about.

The Sunday Times 25.7.76.

Around the world, freedom is disappearing. The erosion is constant, but it is also usually slow. Swift and absolute murder of liberties is still something governments try to conceal. It might cast doubt on their freedom-loving pretensions, and even evoke a protest. Just such a destruction is being perpetrated, however, not by one government but by many. What they plan is not murder, but mass murderof the right to the semblance of a free Press in developing countries.

Not only would the people of say, India be able to read only official "news" about their own country, as is already the case. By a conspiracy between all the governments against their peoples, each would authorise only the official "news" about every other to cross the national frontier. The governments, in other words, will exchange and circulate each other's propaganda, and exclude every other source of news.

Certainly both American and British newspapers are sometimes in danger of neglecting "development" issues until they impinge on Great Power politics-or until one of their own journalists is arrested. But the specific case against the agencies' journalism has rarely been put to them. It is, in fact, little more than a slogan. It does not spring from any genuine desire on the part of Third World governments for the publication of truth. The motive is control, and the verbiage attaching to it originates in a genuine disbelief in anything which educated men understand by freedom.

The International Herald Tribune 20.7.76.

A major movement appears to be under way by Third World and Latin American countries that would restrict the free flow of news reporting in and out of these areas and eventually replace it exclusively with government controlled information.

The trend is called "developmental journalism" by those who espouse it. Its rationale, in the view of its adherents, is that most news about developing countries comes from international news agencies and that this news is distorted.

The language used in Delhi and the language in the background papers for Unesco are parallel-the exact arguments, the same phrases, the same inferences to "cultural imperialism", which is "strictly a Marxist approach to journalism," said Leonard Sussman, executive director of Freedom House.

Newsweek 6.9.76.

To most press libertarians and international newsgathering organisations, the trend is a profoundly ominous one-a portent of Orwellian mind control on a continental scale ...

The (Costa Rica) meeting's controversial proposals - urging state investment in mass communication-struck some observers as a euphemism for state control of the media. "The purpose of the recommendations" charged the Inter-American Press Association "is to dehumanise society ... If the evil is allowed to spread, 1984 will arrive ahead of time for most of the world's population." What alarms many, however, is that UNESCO's sponsorship of the Costa Rica meeting seemed to make repression respectable. 